\title{
PENERAPAN STRATEGI PENJUALAN PRODUK ORGANIK DALAM UPAYA MENINGKATKAN DAYA BELI KONSUMEN (STUDI KASUS P.T. HERO SUPERMARKET CIKAMPEK)
}

\author{
Rieke Retnosary \\ Universitas Buana Perjuangan Karawang \\ rieke.retnosary@ubpkarawang.ac.id
}

\begin{abstract}
ABSTRAK
Penerapan Strategi Penjualan Organik Dalam Upaya Meningkatkan Daya Beli Konsumen dengan studi kasus di Supermarket Giant Express Cikampek di bawah P.T. Hero merupakan judul penelitian ini. Penelitian ini dilakukan untuk membuktikan fenomenafenomena pembelian produk organik berupa sayuran dan buah-buahan yang terjadi di supermarket yang berada di kota Cikampek dengan rata-rata masyarakat berpendidikan dari SMA sampai perguruan tinggi dan berpenghasilan rata-rata menengah ke atas.

Dalam proses pencarian data, peneliti melihat kurangnya antusiasme masyarakat sebagai konsumen Supermarket Giant Express Cikampek untuk membeli produk Organik.

Fenomena ini diakibatkan oleh strategi penjualan yang tidak berfokus pada produk organik, kesadaran akan nilai manfaat masih dipengaruhi harga, jenis produk yang ditawarkan tidak bervariasi dan merujuk pada hasil penelitian yang dilakukan dan terdahulu, informasi sebagai strategi penjualan dan sertifikasi terhadap produk organik sangat memengaruhi daya beli konsumen.
\end{abstract}

Kata Kunci : Penerapan strategi penjualan, fenomena produk organik, daya beli konsumen

\section{PENDAhUluan}

Pergeseran nilai mutu dalam penjualan produk konsumsi menjadi sangat positif. Pemanfaatan lahan untuk konsumsi organik terutama buah dan sayur semakin meluas. Gerai-gerai organik dan supermarket-supermarket menawarkan bahan dasar untuk diolah menjadi makanan bahkan makanan yang siap dimakan dan siap saji ditawarkan dengan sangat beragam. Ini mengindikasikan bahwa semakin sadarnya masyarakat untuk mengonsumsi makanan sehat baik bagi dirinya sendiri maupun keluarganya atau bahkan orang disekitarnya. Modal besar untuk perawatan secara organik sehingga memberikan penawaran dengan harga yang cukup tinggi dibandingkan dengan makanan dengan pengawet atau penggunaan pestisida menjadi tidak membuat produsen mundur dalam penawarannya. 
Menurut Environmental Protection Agency (EPA) menganggap 60\% dari semua herbisida atau pembasmi gulma, 90\% dari semua fungisida atau pembasmi jamur, 30\% dari semua insektisida atau pembasmi serangga merupakan penyebab kanker yang potensial (Gema Ganesa, 29 Oktober 2013), sehingga konsumen tertentu (yang memiliki kesadaran tinggi) memilih untuk beralih peda organik.

Tetapi, data tersebut masih belum berlaku untuk daerah tertentu, kesadaran tidak menjadi orientasi utama bagi keputusan konsumen membeli. Faktor klasik yang menjadi masalah adalah harus mengeluarkan dana lebih untuk mengonsumsi produk organik. Hal ini berlaku di Supermarket Giant Express Cikampek yang berlokasi di Jl. Ir. H. Djuanda Kotabaru Cikampek kabupaten Karawang ( dibawah naungan P.T. HERO Departemen Store)

Lokasi Supermarket sangat strategis karena berada di pinggir jalan raya lintasan kendaraan besar dan pribadi untuk keluar masuk tol Kopo, Purwakarta dan tiga perumahan besar yang berada di sekitarnya, yaitu Perumahan Sukaseuri dengan jumlah kepala keluarga sebanyak 250 orang terdiri dari Blok A sampai dengan Blok T dimana setiap keluarga terdiri dari 3 sampai 5 anggota keluarga yang tinggal. Perumahan Rawa Mas dengan dan Perumahan Cikampek Indah yang masing-masing memiliki jumlah hunian tidak kalah banyaknya. Rata-rata hunian tersebut memiliki pekerjaan yang mapan dan berpendidikan SMA sampai perguruan tinggi. Posisi di depan supermarket tersebut adalah SMAN 1 Cikampek yang seringkali siswa dan guru SMAN 1 tesebut berbelanja ke tempat ini.

Meskipun disekitar Supermarket terdapat 4 mini market, tidak menjadi persaingan besar baginya untuk menawarkan produk organik karena minimarket-minimarket yang ada tidak memberikan penawaran yag sama atas beberapa produk termasuk produk organik.

Sayangnya, penulis melihat lemahnya penjualan produk organik yang ditawarkan. Konsumen lebih memilih bahan dasar dan buah-buahan non organik. Banyaknya produk yang membusuk dan dijual lebih murah dari harga sebelumnya (fresh price to discount price). Sementara dilihat dari fenomena yang ada, asumsi peneliti adalah dikarenakan penawaran harga produk konsumsi organik jauh lebih mahal, karena jika di lihat dari sisi penyajian (display case) sudah sangat baik dan menarik. Dilihat dari International Journal Of Hospital \& Tourism Administration yang membahas tentang restoran layanan cepat menuju hijau (Going Green In Quick-Service Restaurants) dalam Jurnal Rieke Retnosary dimana temuan menujukkan kebanyakan orang (konsumen) tidak bersedia membayar harga yang lebih tinggi bagi praktek hijau (/organik).

Tujuan dari setiap pemasaran produk selalu mengarah pada orientasi laba (profit oriented) dan kecerdasan membaca pasar adalah membawa aspek psikologi agar konsumen dan calon konsumen merasa diperhatikan baik secara langsung maupun tidak langsung dengan menyiapkan apa yang dibutuhkan dan apa yang menjadi keinginannya.

\section{TINJAUAN PUSTAKA}

\section{Manajemen}


Definisi Manajemen Menurut Para ahli

1. Malayu S.P. Hasibuan (2011: 2-3) dalam bukunya Manajemen Dasar, Pengertian, Dan Masalah menuliskan arti manajemen sebagai ilmu dan seni mengatur proses pemanfaatan sumber daya manusia dan sumber-sumber lainnya secara efektif dan efisien untuk mencapai tujuan tertentu.

Malayu sendiri mengambil pandangan beberapa ahli yang mendefinisikan tentang manajemen, yaitu :

- Menurut Andrew F. Sikula, ” Management in general refers to planning, organizing, controlling, staffing, leading, motivating, communicating, and decision making activities performed by any organization in order coordinate the varied resources of the interprise so as to bring an efficient creation of some product or service".

- Menurut Harold Koontz dan Cyril O’Donnel, "Management is getting things done through people. In bringing about this coordinating of group activity, the manager, as a manager plan, organizes, staffs, direct, and control the activities other people".

2. Sedangkan Irfan Fahmi (2014:2) dalam bukunya Manajemen Teori, Kasus, dan Solusi menuliskan beberapa pandangan para ahli tentang arti manajemen, yaitu :

- Manajemen menurut Ricky W. Griffin merupakan suatu rangkaian aktivitas (termasuk perencanaan dan pengambilan keputusan, pengorganisasian, kepemimpinan, dan pengendalian) yang diarahkan pada sumber-sumber daya organisasi (manusia, finansial, fisik, dan informasi) untuk mencapai tujuan organisasi dengan cara yang efektif dan efisien.

- Manajemen menurut George R. Terry dan Leslie W. Rue adalah suatu proses atau kerangka kerja, yang melibatkan bimbingan atau pengarahan suatu kelompok orang-orang ke arah tujuan-tujuan organisasi organisasional atau maksud-maksud yang nyata

- Manajemen menurut James A. F. Stoner adalah proses perencanaan, pengorganisasian, pemimpinan, dan pengendalian upaya anggota organisasi dan penggunaan semua sumber daya organisasi untuk mencapai tujuan yang telah ditetapkan.

Berdasarkan pendapat para ahli tersebut dapat disimpulkan bahwa, manajemen merupakan proses kegiatan masukan (input) sampai keluaran (output) dimana prosesnya terdiri atas perencanaan, pengorganisasian, pergerakan/ mobilisasi dan pengontrolan dari sumber daya manusia dan atas sumber-sumber penunjang (alam terbarharukan dan tidak terbaharukan) yang saling berkesinambungan.

Tujuan Manajemen

H.B Iswanto (2005) dalam menuliskan bahwa setiap manajemen memiliki tujuan yang harus dapat direalisasikan, dimana menggambarkan cakupan tertentu dan menyarankan pengarahan kepada usaha seorang manajer.

Aset paling utama dari fungsi manajemen adalah manusia (sumber daya manusia). Menurut Ike Kusdyah Rachmawati (2008 : 60, 63) dalam organisasi, dimana organisasi atau lembaga menggunakan perencanaan sumber daya manusia untuk meningkatkan efisiensi dan produktivitasnya 
dalam jangka panjang. Organisasi harus merekrut tenaga kerja yang berkualitas tinggi untuk dipekerjakan sehingga dapat bekerja secara produktif.

Setiap organisasi memiliki tujuan dan sasaran bagaimana mereka beroperasi, demikian pula dengan aktivitas perencanaan sumber daya manusia memiliki tujuan yang berdasarkan pribadi/ individu sekaligus organisasi. Tujuan ini memuat sumber daya yang representatif untuk kepentingan jangka panjang organisasi.

Faktor-faktor yang perlu diperhatikan dalam perumusan tujuan :

1) Sejarah

Latar belakang organisasi akan menentukan karakteristik organisasi.

2) Kemampuan organisasi

Kemampuan organisasi harus di dasari pada kelebihan, daya saing, dan nilai lebih

3) Lingkungan organisasi

Aspek lingkungan menciptakan variabel kesempatan dan ancaman bagi organisasi. Analisis ini adalah refleksi dari Strenght, Weakness, Opportunity, dan Threat (analisis SWOT). Organisasi harus dapat melakukan identifikasi SWOT untuk mengetahui sejauh mana kemampuan dan posisi organisasi dibanding pesaing.

4) Fokus pada pasar

Fokus pada tujuan merupakan refleksi dari visi, misi, dan tujaun organisasi.

5) Dapat dicapai

Setiap jenjang manajemen harus memahami tujuan dan sasaran organisasi sehingga tidak memiliki perbedaan persepsi anatar manjemen. Ketika manajemen dan karyawan sudah bersinergi, maka tujaun organisasi dapat tercapai.

6) Dapat memotivasi

Motivasi dipengaruhi oleh faktor kepemimpinan manjemen. Kualitas kepemimpinan yang baik, akan membawa organisasi menjadi lebih baik.

7) Spesifik

Tujuan yang spesifik akan mempermudah pengambilan keputusan karena terarah dan pedoman mutlak.

\section{Manajemen Pemasaran Dan Manajemen Penjualan}

1. Manajemen Pemasaran

William J. Shultz dalam Buchari Alma (2011:130) mendefinisikan bahwa, "Marketing Management is the planning, direction and control of the entire marketing activity of a firm or division of a firm". Sedangkan menurut Ben M. Enis, "Marketing management is a process of increasing the effectiveness and or efficiency by which marketing activities are performed by individual or organizations". 
Dalam pemetaan siklus manajemen pada Buchari Alma (2011:131) dijelaskan dengan pendekatan sistem (system approach) secara umum,

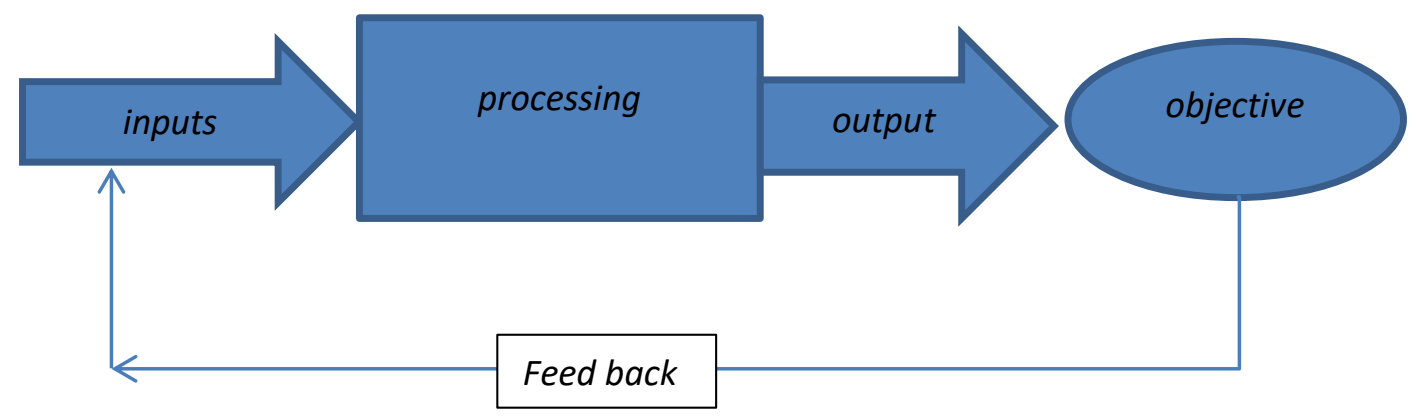

Gbr. 1 Pendekatan Sistem Manajem Pemasaran

Penjelasan pemetaan tersebut adalah bahwa, setiap keberhasilan kegiatan manajemen pemasaran pada sebuah organisasi/ perusahaan, diperlukan masukan (input). Masukan ini dapat menggambarkan informasi di lingkungan sehingga mengetahui kegiatan pasar dan kompetitor. Dengan informasi yang akurat, dilakukan proses untuk mengambil keputusan sehingga akan menghasilkan keluaran (output) berupa keputusan tujuan yang terbaik dan strategis. Keputusan yang strategis dilaksanakan kemudian dapat dilihat hasil imbal balik (feedback) dari kegiatan tersebut.

Philip Kotler dan Lane Keller (2009:5) menuliskan bahwa, manajemen pemasaran terjadi ketika setidaknya satu pihak dalam sebuah pertukaran potensial berfikir tentang cara-cara untuk mencapai respon yang diinginkan pihak lain. Manajemen pemasaran sendiri dipandang sebagai seni dan ilmu memilih pasar sasaran dan meraih, mempertahankan, serta menumbuhkan pelanggan dengan menciptakan, menghantarkan, dan mengomunikasikan nilai pelanggan yang unggul.

2. Manajemen Penjualan

Shultz dalam Buchari Alma (2011:132-133) membedakan anatara manajemen pemasaran (marketing management) dan manajemen penjualan (sales management).

"Sales management is the planning, directing, and control of the personal selling activities of the business". Jadi. Manajemen penjualan ini khusus merencanakan, mengarahkan, dan megawasi penjualan pada sebuah perusahaan.

Kegiatan manajemen penjualan sangat erat kaitannya dengan manajemen pemasaran. Tetapi, kegiatan manajemen pemasaran jauh lebih luas, yaitu: merencanakan, mengorganisasikan, melaksanakan, dan mengawasi kegiatan yang berhubungan dengan produk, pembelian, kebijakan harga, promosi, penjualan, riset, penggudangan, pengangkutan, pemberian kredit, mencari permodalan, manajemen resiko, mencari daerah penjualan, saluran distribusi, dan lain sebagainya guna mencapai tujuan perusahaan. 


\section{Strategi Pemasaran}

Manajemen Pemasaran Strategis menurut David A. Aaker ( 2013:13-17) adalah sebuah sistem yang dirancang untuk membantu manajemen menciptakan, mengubah, atau mempertahankan sebuah strategi usaha dan untuk menciptakan visi strategis. Visi strategis adalah sebuah proyeksi dari sebuah strategi di masa depan atau seperangkat strategi.

Dalam kegiatan pemasaran, manajemen harus memiliki strategi tertentu untuk mengetahui pasar. Kegiatan yang dilakukan adalah menganalisis setiap bagian yang akan membantu pencapaian tujuan. Analisis yang dilakukan adalah analisis strategi.

Analisis strategi terbagi atas analisis eksternal dan analisis internal. Analisis eksternal adalah analisis keadaan di luar lingkungan perusahaan, yang terdiri atas peluang pasar dan ancaman terhadap produk yang dipasarkan.

Analisis eksternal terdiri dari :

1) Analisis pelanggan (segmentasi, motivasi, dan kebutuhan yang belum terpenuhi)

2) Analisis competitor (identitas, kelompok strategis, performa/ kinerja, kesan, tujuan, strategi, dan kelemahan)

3) Analisis pasar, hambatan masuk, struktur biaya, sistem distribusi, tren, dan faktor kunci sukses)

4) Analisis lingkungan (teknologi, konsumen, pemerintah/ perekonomian, scenario, dan area yang membutuhkan informasi)

Analisis internal merupakan analisis di dalam perusahaan yang terdiri dari kelemahan manajemen dan kekuatan manajemen terhadap pasar. Analisis yang harus diperhatikan terdiri dari:

1) Analisis kinerja (profitabilitas, penjualan, analisis nilai pemegang saham, kepuasan konsumen, kualitas produk, asosiasi merk, biaya relative, produk baru, serta kemampuan dan kinerja karyawan)

2) Penentuan pada pilihan strategis (permasalahan strategi, halangan/ hambatan, kekuatan, kelemahan, dan kewajiban/ liabilitas)

Dari kedua analisis tersebut, maka manajemen harus membuat, mengadaptasi, dan menerapkan strategi berupa :

1) Mengidentifikasi berbagai alternatif strategi usaha:

- Strategi-strategi investasi pasar produk

- Proposisi nilai pelanggan

- Asset, kompetensi, dan sinergi

- Strategi dan program fungsional

2) Memilih strategi 
3) Menerapkan rencana pengoprasian

4) Mengkaji dan menyesuaikan strategi

Dari kegiatan analisis, dicapailah tujuan strategisnya. Dimana tujuan-tujuan strategis menurut David A. Aker (2013:17-18), yaitu:

1) Mengedepankan pertimbangan dari pemilihan strategi

2) Membantu sebuah usaha untuk dapat mengatasi perubahan

3) Mendorong sebuah pandangan yang jauh

4) Membuat keputusan pengalokasian sumberdaya menjadi nyata

5) Membantu analisis strategis dan pengambilan keputusan

6) Memberikan sebuah manajemen strategi dan sistem kendali

7) Memberikan sistem komunikasi dan koordinasi horizontal dan vertical

\section{Kepuasan Pelanggan}

Fandi Tjiptono dan Gregorius Chandra (2011: 105,292-298) menuliskan bahwa kepuasan pelanggan adalah salah satu kegiatan hasil analisis internal yang dilakukan oleh perushaan/ organisasi. Kepuasan pelanggan merupakan bagian dari kebijakan dan strategi produk dalam ruang lingkup manajemen pemasaran. Cakupan kebijakan dan strategi produk salahsatunya adalah strategi pengembangan produk dimana diharapkan dapat terwakilinya keinginan dan harapan pelanggan.

\section{Perilaku Konsumen}

Perilaku konsumen pada dasarnya dipengaruhi oleh kebutuhan, keinginan dan permintaan.

Inilah yang menjadi peluang pasar, perusahaan sebagai penyedia permintaan/ produsen harus mampu mengambil peluang dari keinginan pasar bahkan harus bisa mengendalikan pasar. Sehingga tujuan perusahaan tercapai.

Tujuan mempelajari dan menganalisis perilaku konsumen adalah :

1) Untuk mengimplementasikan konsep pemasaran sebagai rencana memengaruhi calon konsumen

2) Untuk memahami pengaruh yang kompleks ketika konsumen mengonsumsi produk yang dibeli

3) Untuk meningkatkan kepercayaan diri manajer (pemasaran), memprediksi respon konsumen setelah strategi pemasaran ditetapkan dan dilaksanakan

4) Untuk menghindari kriteria rujuk-diri (self-reference criterion). Setiap konsumen memiliki tingkat pemahaman yang berbeda-beda tentang produk yang dibelinya. Ada yang tingkaat pemahamannya tinggi, ada juga yang rendah.

\section{Kajian Penelitian Terdahulu}

1. Penjualan buah-buahan dan sayuran organik rata-rata memiliki korelasi positif dan memberi sumbangan positif dari $13 \%$ sampai dengan $86,9 \%$ pada peminatan (The impact Organic Mainstream Movement: Case Study Of England Organic Produce Price, Tesis Megan M. Dolan University of Massachusetts Amherst. Pebruari 2008). 
2. Green Marketing berpengaruh secara langsung dan signifikan terhadap minat pembeli; tidak berpengaruh secara langsung dan dan signifikan terhadap keputusan pembelian; berpengaruh secara langsung terhadap keputusan pembelian; minat membeli berpengaruh secara tidak langsung dan signifikan terhadap keputusan pembelian dengan minat membeli sebagai variabel intervening (Green Marketing dan Pengaruhnya terhadap Keputusan Pembelian Melalui Minat Membeli Produk Organik, Tesis Allen A.CH. Manongko. 2011).

3. Menganalisis prilaku pelanggan melalui makanan hijau (green food), survei dengan 50 responden di Dhaka, Bangladesh menghasilkan respon positif pelanggan terhadap makanan hijau dengan implikasinya terhadap kerjasama pelanggan, supplier, produsen dan pemerintah membangun pasar makanan hijau dinegaranya (Consumer's Attitude Towards Purchasing Green Food, European Journal of Business and Management. Md. Saiful \& Iffat Zabin. 2013)

\section{METODE PENELITIAN}

Metode Penelitian adalah kualitatif dengan pendekatan multiple case study.

Informasi berulang dan terus menerus (snowball) dengan wawancara untuk mendapatkan hasil yang sesuai (data jenuh).

Adapun prosedur penelitain/ prosedur kerja yang dilakukan adalah sebagai berikut : 


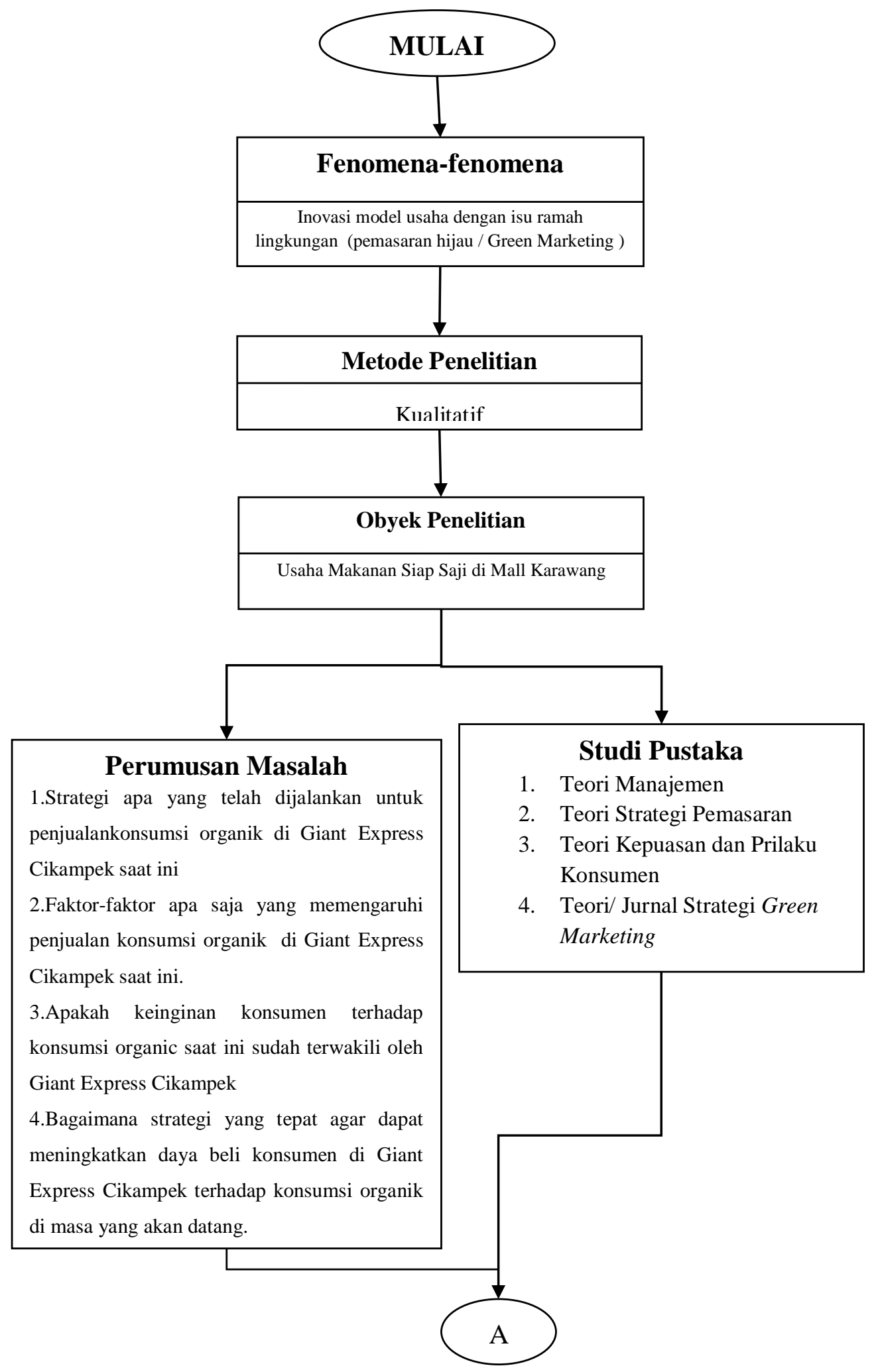

Gambar 3.1

Diagram Prosedur Kerja 


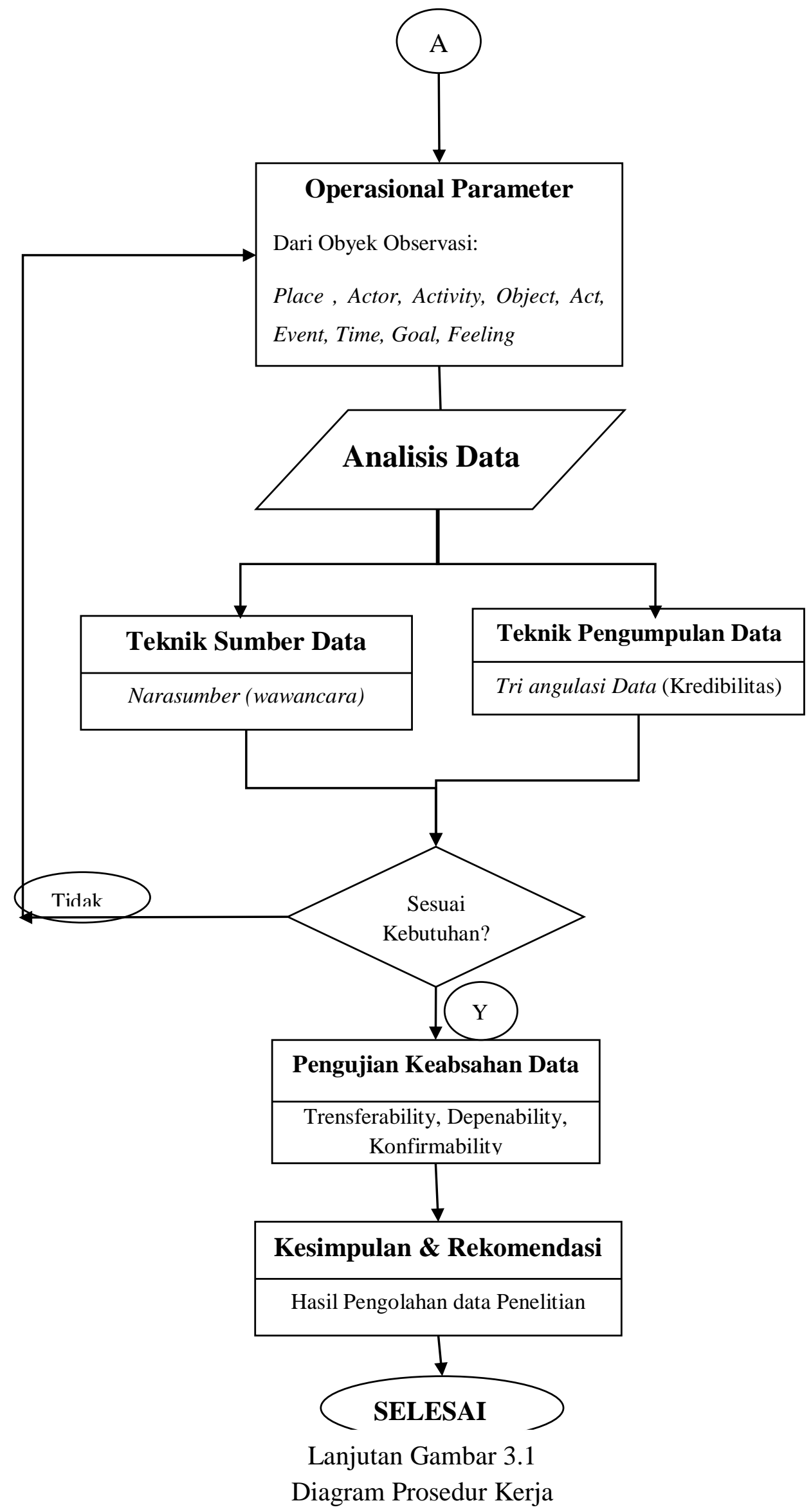




\section{HASIL DAN PEMBAHASAN}

Jumlah Responden $=30$ orang

Jenis kelamin $=$ wanita $($ Ibu rumah tangga $)$

Rentang usia $=31-65$ tahun

Latar belakang pendidikan $=$ SMA $\&$ S 1

Pendapatan Rata-rata $=3.000 .000-4.5000 .000$

Jumlah Keluarga dalam satu hunian $=2-4$ orang

Tabel Data 4.1 Daya Beli :

\begin{tabular}{|l|l|l|l|l|l|}
\hline No. & $\begin{array}{l}\text { Jumlah } \\
\text { Konsumen }\end{array}$ & $\begin{array}{l}\text { Sayur/buah } \\
\text { biasa di beli }\end{array}$ & $\begin{array}{l}\text { Buah yang } \\
\text { biasa dibeli }\end{array}$ & $\begin{array}{l}\text { Alasan tidak } \\
\text { membeli } \\
\text { organik }\end{array}$ & $\begin{array}{l}\text { Harapan } \\
\text { membeli sayur/ buah } \\
\text { organik }\end{array}$ \\
\hline 1 & 1 & impor & Organik & Sama saja & Murah \\
\hline 2 & 2 & lokal & Organik & Sama saja & Murah \\
\hline 3 & 2 & impor & Non-organik & Sama saja & Murah \\
\hline 4 & 5 & impor & Non-organik & mahal & Murah \\
\hline 5 & 5 & lokal & Non-organik & Sama saja & murah \\
\hline 6 & 1 & lokal & Non-organik & Tidak lengkap & Lebih lengkap \& \\
\hline 7 & 14 & lokal & Non-organik & Mahal & Murah \\
\hline
\end{tabular}

Pembahasan yang didapatkan dari proposisi dengan hasil penelitian adalah :

\section{Penerapan strategi manajemen Supermarket Giant Express Cikampek}

Penerapan strategi tidak mewakili produk organic sehingga belum mampu meningkatkan minat konsumen untuk membeli produk sesuai dengan proposisi awal. Karena Giant Express tidak berkonsentrasi untuk menjual produk organik saja, melainkan penawaran produk impor dan lokal khusus. Strategi yang dilakukan hanya penawaran-penawaran potongan harga dan tata letak penjualan saja. Dalam teori strategi promosi (Paul Mali dalam Sofjan Assauri. 2011: 14) bahwa strategi promosi penjualan, personal selling dan strategi publisitas sangat membantu dan menjamin produk yang ditawarkan akan diminati oleh konsumen. Pengenalan produk organik jauh lebih efektif dengan publisitas khusus seperti banner, informasi karyawan terhadap pelanggan, dan penyimpanan khusus produk organik seperti yang dilakukan oleh supermarket-supermarket lain yang terletak di luar kota Cikampek.

Daya beli konsumen di Giant Express sangat baik karena menurut Store Manager, rata-rata konsumen yang datang ke Giant Express lebih dari 2000 konsumen setiap harinya, sedangkan weekend days (sabtu-minggu) mencapai 5000 - 6000 konsumen Seharusnya ini menjadi nilai tersendiri untuk memperkenalkan produk organik pada konsumen. 
Ini tidak menjadi efektif karena hasil analisis internal juga menyatakan daya beli produk organik kurang memuaskan di wilayah Cikampek ini karena dianggap mahal sehingga diambil kebijakan untuk meminimalkan penjualan produk organic tersebut.

\section{Faktor-faktor yang memengaruhi penjualan produk organik di Supermarket Giant Express Cikampek}

Dari data Responden sebanyak 30 orang yang berlatar belakang ibu-ibu Rumah Tangga peneliti mendapat faktor-faktor yang membuat konsumen tidak mau membayar lebih dari penjualan produk organik adalah pengetahuan yang minim karena:

1. Kurangnya informasi tentang nilai manfaat dari produk tersebut,

2. Sikap menyamakan produk dan

3. Prilaku yang tidak terbiasa atau belum terbiasa dengan produk.

Hal ini didapatkan berdasarka data 10 dari 30 responden atau 33,33\% menyatakan demikian.

4. Produk organik di Supermarket Giant Express Cikampek tidak mewakili kebutuhan konsumen

Dalam proses kegiatan penelitian sampai akhir penelitian, penjualan produk organik ternyata belum mewakili kebutuhan konsumen. Karen peneliti pada saat itu hanya menemukan satu jenis penjualan produk organik yaitu wortel. Menurut karyawan yang bertanggung jawab, hal ini memang dilakukan oleh pusat. Seringkali hanya dua atau tiga jenis buah dan atau sayur saja yang disediakan. Jika dirujuk dari pernyataan store manager, ini diakibatkan minat dari konsumen Cikampek yang kurang terhadap produk tersebut.

Hasil dari wawancara, ternyata 1 dari 29 responden cukup jeli dengan penawaran organik. Responden sendiri menjawab bahwa kebutuhan akan organik seringkali tidak dibarengi dengan penawaran oleh Giant Express, sehingga responden tidak dapat memilih yang sesuai dengan apa yang dibutuhkan. Ini mengindikasikan bahwa prosentase 3,33\% (1 banding 29) responden memahami pentingnya konsumsi produk organik tanpa melihat berapa dana yang harus dikeluarkan untuk melakukan pembelian.

5. Harga yang mahal

19 dari 30 responden atau 63,33\% menyatakan bahwa produk organik cenderung mahal. Ini mengindikasikan bahwa rata-rata masyarakat Cikampek yang diwakili oleh 30 responden menyatakan hal yang sama.

\section{Strategi yang tepat untuk meningkatkan penjualan produk organik di Supermarket Giant Express Cikampek}

Strategi yang tepat dari hasil penelitian ini adalah :

a. Harga yang bersaing.

b. Informasi yang menjelaskan nilai manfaat dari buah dan sayur organik dibandingkan non-organik sehingga konsumen memahami pentingnya menggonsumsi buah dan sayur organik.

c. Informasi perawatan dan perlakuan atas buah dan sayur organik sehingga konsumen memahami benar pentingnya menjaga kualitas buah dan sayur organik tersebut. 
d. Menambah variasi produk buah dan sayur yang lebih banyak.

\section{KESIMPULAN DAN SARAN}

\section{Kesimpulan}

Dari hasil penelitian dan pembahasan, dapat disimpulkan bahwa :

1) Penerapan strategi penawaran dan/ penjualan produk organik di Supermarket Giant Express Cikampek saat ini belum mampu meningkatkan minat konsumen untuk membeli produk organnik.

2) Faktor-faktor yang menjadi kendala sehingga memengaruhi penjualan produk organik di Supermarket Giant Express Cikampek saat ini

a. Harga yang ditawarkan dari buah dan sayur organik

b. Kurangnya informasi keuntungan mengonsumsi buah dan sayur organi, termasuk sikap dan prilaku yang terbisa dengan produk lokal dan impor.

c. Pilihan lain berupa buah dan sayur organik

d. Tidak lengkapnya pilihan

3) Keinginan konsumen terhadap produk organik di Giant Express Cikampek sekarang ini tidak terlalu besar dan yang akan datang harus dapat menjadi fokus bagi Giant Express Cikampek jika memang berlaku sebagai produsen yang peduli terhadap kesehatan konsumennya sebagai efek sosial.

4) Strategi yang tepat untuk meningkatkan daya beli konsumen Giant Express Cikampek terhadap produk organik adalah dengan memberikan apa yang diminta konsumen sehingga konsumen akan terpengaruh oleh penawaran-penawaran atas produk organik.

\section{Rekomendasi}

Rekomendasi peneliti diberikan pada :

\section{Manajemen Supermarket Giant Express :}

1. Strategi penjualan di Giant Express atas produk Organik harus diubah karena nilai manfaat yang terkandung didalamnya. Kesadaran untuk penawaran sehat bagi konsumen dijadikanprioritas dan tanggung jawab bersama terutama bagi Giant Express dimana konsumen banyak sekali menggunakan penawaran-penawaran produknya. Cara-cara yang dapat diambil adalah dengan memahami faktorfaktor yang diklasifikasikan ke dalam kategori seperti faktor demografi, pengetahuan konsumen, nilai produk dimata konsumen, sikap-sikap konsumen terhadap produk, dan prilaku-prilaku keseharian rata-rata konsumen agar yang akan datang konsumen mau membayar lebih dari penjualan produk yang ditawarkan.

2. Meningkatkan daya beli konsumen 
Cara-cara yang dapat diambil adalah dengan :

a. Standing Banner disimpan di depan show case buah dan sayur.

b. Pemasangan informasi yang terlihat oleh konsumen seperti di dinding dengan gambar-gambar yang menyenangkan dan membuat tertarik konsumen

c. Daftar harga yang kompetitif dan perbandingan dari nilai manfaat yang didapat

d. Karyawan yang bertindak seperti pramusaji untuk memberikan informasi dengan seragam atau maskot.

3. Menekan faktor-faktor yang memengaruhi penjualan produk organik dengan cara positif terhadap keinginan konsumen termasuk harga.

\section{Konsumen Supermarket Giant Express :}

1. Informasi yang diberikan di media atau pihak Supermarket Giant Express atas nilai manfaat dari produk organik harus dijadikan referensi jangka panjang.

2. Penghematan atas pendapatan untuk memilih produk organik harus menjadi alasan terakhir demi nilai manfaat didalamnya.

3. Positif atas penawaran-penawaran produk organik

\section{DAFTAR PUSTAKA}

\section{Buku}

Buchari Alma. 2011. Manajemen Pemasaran \& Pemasaran Jasa. p. 130 - 133

David A. Aaker. 2013. Manajemen Pemasaran Strategi. Salemba Empat. Jakarta. p. 13 - 18

Etta M. Sangadji \& Sopiah. 2013. Perilaku Konsumen. Andi Yogyakarta. P. $11-12$

Fandi Tjiptono dan Gregorius Chandra. 2011. Service, Quality \& satisfaction. ANDI, Yogyakarta. $P$. 105,292-298

Fred R. David. 2012. Manajemen Strategi Konsep. Salemba. Bandung. p. 198 - 203

H.B. Iswanto. 2005. Pengantar Manajemen. Bumi aksara

Irfan Fahmi.2014. Manajemen Teori, Kasus, dan Solusi. Alfabeta. Bandung. P. 2

Lexy J. Moleong. 2014. Metodologi Penelitian Kualitatif. Remaja Rosda Karya.Bandung. $P$. $4-6,34,37,331-332$

Malayu S.P. Hasibuan. 2011. Manajemen Dasar, Pengertian, Dan Masalah. P. 2 - 3

Paul Mali dalam Sofjan Assauri. 2011. Manajemen Pemasaran. Dasar, Konsep \& Strategi. $P$ 14

Ujang Sumarwan. 2012. Riset Pemasaran dan Konsumsi. P. 221

Sugiyono.2012. Metode Penelitian Kuantitatif, Kualitatif dan R\&D. Alfabeta. Bandung. $P$. $220,230-231,246-252,277$ 


\section{Jurnal Dan Tesis}

Allen A. Ch. Manongko. 2011. Tesis. Green Marketing Dan Pengaruhnya Terhadap Keputusan Pembelian Melalui Minat membeli Produk Organik.

Carolyn Dimitri, dkk. 2008. Local Marketing of Organic Food by Certified Organic Processors, Manufacturers, and Distributors. Journal of Agribusiness 26,2 (Fall 2008): $157-174$

Md. Saiful Islam \& Iffat Zabin. 2013. Consumer's Attitude towards Purchasing Green Food. European Journal of Business and Management

Megan M. Dolan. 2008. Tesis. The Impact Of The Organic Mainstream Movement : A case Study Of new England Organic Produce Price

Rieke Retnosary. 2015. Jurnal Manajemen \& Bisnis Kreatif. Green Marketing Application Strategy For Increasing Consumer satisfaction (Case Study In Fast Food Business Company Group At Mall Karawang) 